\title{
Fostering the Key Competencies of Undergraduates Majoring in Primary School Teaching and Learning based on the Standards of PISA International Comparative Study
}

\author{
O.P. Mukoviz ${ }^{1}$, O. V. Kravchuk ${ }^{2}$, L. M. Roienko ${ }^{3}$, T. A. Torchynska ${ }^{4}$, H. P. Voloshina ${ }^{5}$ \\ ${ }^{12345}$ Pavlo Tychyna Uman State Pedagogical University, 2, Sadova Str., 20300, Uman, Ukraine
}

Received: August 4, 2021. Revised: September 7, 2021. Accepted: September 10, 2021. Published: September 13, 2021.

\begin{abstract}
The purpose of the study was to identify how the reshaped curriculum that was based on PISA standards fostered the key competencies of undergraduates majoring in primary school teaching and learning in terms of materials design and teaching methodology used throughout the internships at schools. The study used qualitative and quantitative methods with qualitative methods getting higher priority to enlarge the base of evidence and get a deeper insight into the issues under research. It was found that reshaping the preservice teacher professional training, specifically in test format, materials design, and assessment, and made the shift to training schoolchildren to take PISA-based test was necessary for the school educational settings in Ukraine. The teacher students' awareness of the PISAbased test needed improvement. The training model used in the study along with the internship addressed the loopholes in the university curriculums and training of the students majoring in primary education. The intervention brought a positively challenging experience for the students. It helped them to 'pump up' their intellectual, professional, and technical skills. They raised awareness of the PISA-based test, Blooms' Taxonomy, and test question formulation. The students learned to use DIF and DTF methods to validate the PISA test questions, age specifics in training primary school children in terms of adjusting it taking the PISA-based test, and approaches to creating a positive mindset in primary schoolchildren towards learning through dialogue and cooperation. It was found that the students upgraded their teaching and material design skills and became more confident as teachers in terms of PISA-based test training. Changing the students' perceptions and their teaching approaches were the major difficulties and challenges to the study. They were
\end{abstract}

addressed through mentorship which was used when the students did internships.

Keywords: higher education, pre-service teachers majoring in primary school teaching and learning, key competencies, PISA-based test.

\section{INTRODUCTION}

The process of fostering the key competencies of the undergraduates majoring in primary school teaching and learning is influenced by a shift to a new assessment approach used at schools [1]. This assessment approach - attempted to be standardized through the OECD's Programme for International Student Assessment (PISA) - is becoming more cross-domain with the cyclic change in focus of the assessment involving students' cognitive and metacognitive abilities [2], [3]. It is also considered a comprehensive guideline of how to fine-tune the educational policies. The recent results in PISA 2018 showed that the student's performance is not up to standard meaning that there is the need for reshaping of educational schooling policies and practices along with reshaping of the curriculum of training staff-to-be who are supposed to implement those upgraded policies and PISAbased standards at school [4]. It is common for the national assessments in schools in Ukraine that a country-wide standard of school-level outcome is not set. It suggests that teachers and exam judges grade the 15-year-olds' learning achievements quite subjectively, often lacking teachers' reasoning when making grading decisions. This implies that there is a need for a framework to organise the experts' judgments into meaningful scores [5].

Given the fact that this test is currently adapted in schools in Ukraine [5], it inspired this study that is aimed at reshaping the curriculum for the primary school student teachers to raise their awareness of PISA and develop the competencies to educate the school children, starting from the early school age, 
in Ukraine so that they were able to succeed in this test when they are 15 years old.

\section{A. Literature review}

The international education benchmarking concept for schools was found to serve as the theoretical framework for PISA-based tests [6]. The concept, when implemented, was supposed to adjust the students' learning performance to a globally accepted standard and in this way to provide equal tertiary educational opportunities to a larger number of young people [7]. It was found that the test was based on the theoretical principles of Bloom's taxonomy [8]. This meant that the questions are formulated and distributed in sequence to cover the specific order thinking skills and cognitive process dimensions such as remember, understand, apply, analyse, evaluate and create. Interestingly, researchers [8], [9] found that the PISA-based test mostly measures how the schoolchildren perform in understanding, analysing, evaluating. The review found that better-performing countries in the PISA assessment use a demanding teacher professional development system and selection procedure which are intended to raise the quality of teaching at all levels at school so that it complies with the PISA format and requirements [10]. Authors opine those teachers should be framed to reshape the curriculum so that it focused on pedagogies based on dialogue to develop student's critical thinking and cooperation skills, active learning to learn through problemsolving (team) assignments and activities, individual learning to contextualise knowledge, and learner autonomy to become a self-paced learner [11]. This teacher framing should start at university and the above skills should be fostered in schoolchildren from early school age. Since the implementation of PISA-based tests is an emerging trend in Ukraine, it creates a gap for the study of the ways how student teachers can be trained to become ready to teach schoolchildren so that they are ready to take and succeed in the test.

Therefore, the purpose of the study is to identify how the reshaped curriculum that is based on PISA standards fosters the key competencies of undergraduates majoring in primary school teaching and learning in terms of materials design and teaching methodology used throughout the internships at schools.

Research questions were as follows:

1) to what extent the student teachers are aware of the PISAbased test.

2) how the reshaped curriculum for undergraduates majoring in primary school teaching and learning fosters the key competencies that are needed to teach schoolchildren so that they are ready for the PISA-based test,

3) how the host educational institutions evaluate the sampled students' professional efficacy while they do internships in terms of PISA-purposed materials design and teaching methodology,

4) how the EG students perceive the upgraded specialismrelated training.

\section{MATERIALS AND METHODS}

The study used qualitative and quantitative methods with qualitative methods getting higher priority to enlarge the base of evidence and get a deeper insight into the issues under research. The above allowed using triangulation in the validation of research outcomes. The methods were employed sequentially [12]. The variables for the study were as follows: undergraduates' awareness of the PISA-based test, teacher skills, the judgments of the representatives of host educational institutions on students' performance in PISA-purposed materials design and teaching methodology, and students' insights into upgraded specialism-related training. The original quiz (see Appendix A) was designed and used to monitor the undergraduates' awareness of the PISA-based test. The teacher aptitude test, (available through the link: https://www.queendom.com/tests/access_page/index.htm?idRe gTest $=3910$ ) was used to measure students' teaching skills. The checklist-based reports provided by the representatives of host educational institutions were used to explore the representatives' opinions on students' performance in PISApurposed materials design and teaching methodology at the beginning of the internship and upon finishing it (see Appendix B: The checklist on students' performance in PISApurposed materials design and teaching methodology). The focus group interview questionnaire was designed to answer the fourth research question.

\section{A. Research design}

The study included four phases such as baseline, transitional, intervention, and data analyses. The first phase used the survey research design. The intervention phase employed a quasi-experimental design with descriptive casestudy features. These characteristics were observations performed by the representatives of host schools [13], [14]. The intervention was organised as a one-group pre-test - posttest measurements-based quasi-experiment [15]. The experiment involved training of the students at university and internship. The data analyses phase consolidated data and produced interpretations (see Figure 1).

The study involved nine secondary schools and two leading pedagogic universities in Ukraine such as Dragomanov National Pedagogical University and Borys Grinchenko Kyiv University. It lasted from January 2020 to January 2021. 


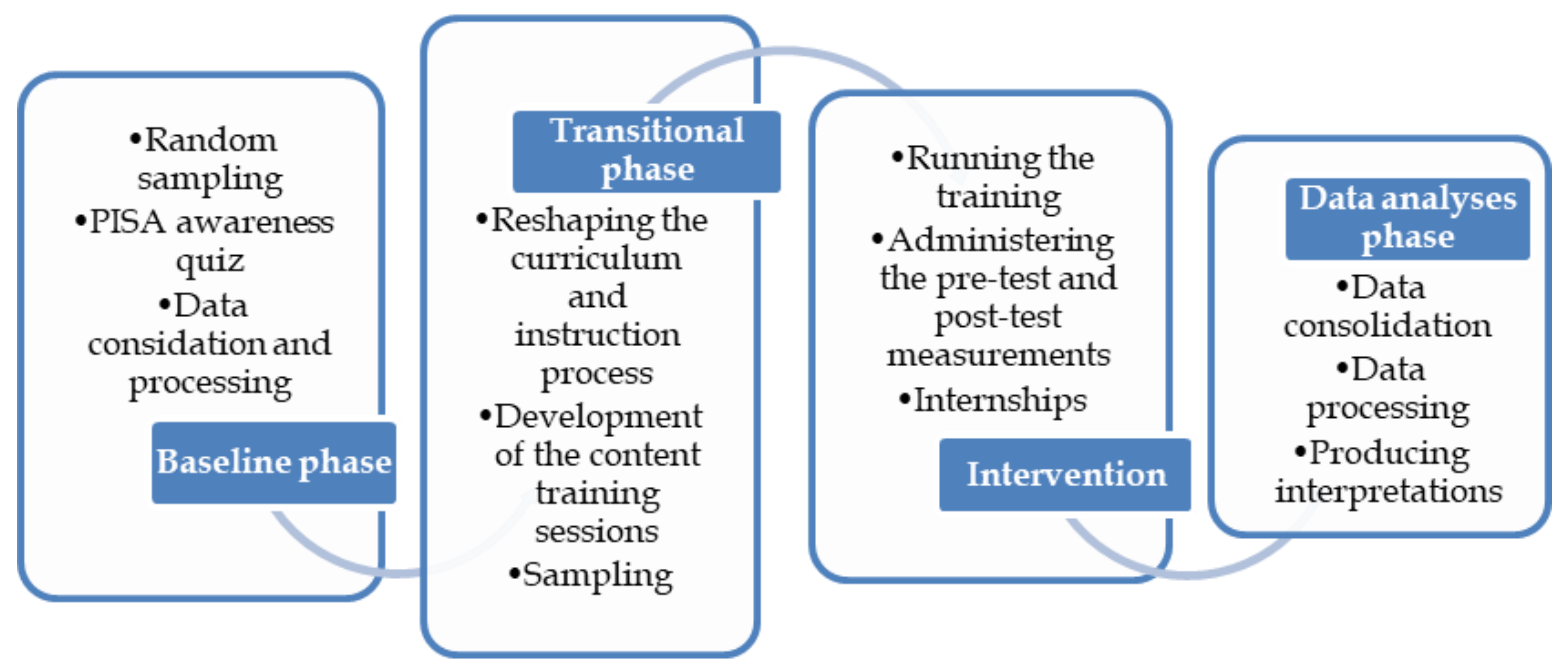

Fig. 1 The four-phase-based research design

\section{B. Intervention description}

This project was planned to raise students' awareness of the PISA-based test and teaching methodology that is related to training primary school students in doing test-related tasks. The project was aimed at deepening the EG students' professional knowledge and skills in designing the PISApurposed materials to foster primary school children's testrelated skills and abilities. The intervention included the modules for the EG students which were as follows:

Module 1. Ins and outs of PISA-based test

Module 2. Blooms' Taxonomy and test questions

formulation

Module 3. DIF and DTF methods to validate the PISA test questions

Module 4. Age specifics in training primary school children in terms of adjusting it taking the PISA-based test

Module 5. Approaches to creating a positive mindset in primary schoolchildren towards learning through dialogue and cooperation

The assessment was based on the grade point average (GPA) of the ECTS grades obtained by students throughout all the modules.

\section{Sampling}

Two sampling techniques were used throughout the study. These were simple random sampling and convenience sampling. The baseline phase relied on random sampling. The intervention used convenience sampling. The population for the baseline phase consisted of 712 people. They were students $(n=593)$, academic instructors $(n=58)$, and school teachers $(n=61)$. Table 1 illustrates the demographic characteristics of the sampled individuals.
Table. 1. Students' requests expressed in the survey (\%)

\begin{tabular}{|c|c|c|c|c|c|c|}
\hline \multirow{2}{*}{\multicolumn{2}{|c|}{$\begin{array}{c}\text { Characteristic } \\
\mathrm{s}\end{array}$}} & \multicolumn{3}{|c|}{ Group of respondents } & \multirow[b]{2}{*}{$\begin{array}{l}\mathrm{Me} \\
\text { an }\end{array}$} & \multirow[b]{2}{*}{ SD } \\
\hline & & $\begin{array}{l}\text { Students, } \\
\text { n (\%) }\end{array}$ & $\begin{array}{l}\text { Academic } \\
\text { instructors }\end{array}$ & $\begin{array}{c}\text { School } \\
\text { teachers }\end{array}$ & & \\
\hline \multirow{2}{*}{ 离 } & $\begin{array}{c}\text { Males, } \\
n_{\text {popled }}=49\end{array}$ & $31(63.26)$ & $16(32.65)$ & $2(4.09)$ & $\begin{array}{l}16 . \\
33\end{array}$ & $\begin{array}{c}11.8 \\
4\end{array}$ \\
\hline & $\begin{array}{c}\text { Females, } \\
n_{\text {pooled }}= \\
663\end{array}$ & $\begin{array}{c}562 \\
(84.77)\end{array}$ & $42(6.34)$ & $\begin{array}{c}59 \\
(8.89)\end{array}$ & $\begin{array}{c}22 \\
1.0 \\
0\end{array}$ & $\begin{array}{c}241 . \\
22\end{array}$ \\
\hline \multirow{4}{*}{$\underset{\psi}{\ddot{\alpha}}$} & $\begin{array}{c}20-24, \\
n_{\text {pooled }}= \\
598\end{array}$ & $\begin{array}{c}593 \\
(99.16)\end{array}$ & $0(00.00)$ & $5(0.84)$ & $\begin{array}{c}19 \\
9.3 \\
3\end{array}$ & $\begin{array}{c}278 . \\
37\end{array}$ \\
\hline & $\begin{array}{c}25-30, \\
n_{\text {pooled }}= \\
39\end{array}$ & $0(00.00)$ & $27(69.23)$ & $\begin{array}{c}12 \\
(26.89)\end{array}$ & $\begin{array}{l}13 . \\
00\end{array}$ & $\begin{array}{c}11.0 \\
4\end{array}$ \\
\hline & $\begin{array}{c}31-35, \\
n_{\text {pooled }}= \\
60\end{array}$ & $0(00.00)$ & $22(18.03)$ & $\begin{array}{c}38 \\
(13.12)\end{array}$ & $\begin{array}{l}20 . \\
00\end{array}$ & $\begin{array}{c}15.5 \\
7\end{array}$ \\
\hline & $\begin{array}{c}\text { Older than } \\
36, \\
n_{\text {pooled }}=15\end{array}$ & $0(00.00)$ & $9(16.68)$ & $\begin{array}{c}6 \\
(21.42)\end{array}$ & $\begin{array}{c}5.0 \\
0\end{array}$ & 3.74 \\
\hline
\end{tabular}

In the intervention phase, two classes of undergraduates majoring in primary school teaching and learning of 21 students $\left(M \_a g e=21.35, \mathrm{SD}=4.11\right)$ for Dragomanov National Pedagogical University and 23 students (M_age $=22.12, \mathrm{SD}=$ 3.48) for Borys Grinchenko Kyiv University were hired to participate in the experiment. The groups were perceived as mutually homogeneous because the EGs students were of the same major and their grade point average (GPA) was 73.57 (ECTS), $\mathrm{SD}=2.24$. The input Mean score in Teacher Aptitude Test was 43.85, SD = 5.74.

\section{Instruments}

Baseline phase PISA awareness quiz (based on [16], Appendix A (can be accessed via the link: https://forms.gle/4Hc7VAKh5W65GKZ17)

The quiz is based on the "PISA 2021 context questionnaires" by the authors [16]. It consists of 20 questions organised in seven domains such as question types, question- 
wording, response options, scaled indices, routing, matrix sampling, and test format. The test uses a binary scale with "Yes/No" responses. Before being used, it was piloted. Fiftythree student volunteers (aged 21-22) for the above universities were randomly hired to respond to it. Single Sample T-Test Calculator (one-tailed) (available through the link:

https://www.socscistatistics.com/tests/tsinglesample/default.as px) was used for computations. The obtained t-value was 37.72. The value of $\mathrm{p}$ was $<.00001$. The result was significant at $\mathrm{p}<.05$. A negative $\mathrm{t}$-value suggested that there was a reversal in the directionality of the effect, which did not bear on the significance of the difference between groups. The content validity was found valid by the research team members and hired experts. Cronbach's alpha for the internal consistency was .81 and was sufficient [17]. The values intercorrelation ranged between .382 and .433 indicating the significance of the construct validity of the quiz at $\mathrm{p}<.01$. The inter-rater reliability of the quiz was calculated by identifying the Interclass Correlation Coefficient (ICC). The obtained mean value of ICC was 0.54 (95\%; $\mathrm{CI}=0.46-0.56)$. It also showed good validity.

Teacher Aptitude test (available through the link: https://www.queendom.com/tests/access_page/index.htm?idRe gTest=3910)

This is a teacher career test consisting of 250 questions attempting to cover competencies that characterise a good and competent instructor/educator. The questions from 1 to 14 are about teachers' personal behaviours in casual situations and rely on the 5-point Likert frequency scale with 5 meaning 'Always', 4 = 'Often', 3 = 'Sometimes', 2 = 'Rarely', and $1=$ 'Never'. Questions 15-61 are about teachers' behaviours in job-related situations. Questions $62-81$ are on teaching experience reflection. Questions 81-99 are on teaching practice reflection. The above groups of questions are based on the 5-point Likert reflection scale with 5 meaning 'Exactly like me', 4= 'A lot like me', 3 = 'Somewhat like me', 2 = 'A little like me', and $1=$ 'Not at all like me'. Questions 100155are to measure teachers' resilience abilities. This group of questions uses the 5-point Likert reflection scale with 5 meaning 'Completely true', $4=$ 'Mostly true', 3 = 'Somewhat true or false', 2 = 'Mostly false', and 1 = 'Completely false'. Questions 156-175 cover teacher communication skills. the 5point Likert frequency scale with 5 meaning 'Very often', $4=$ 'Often', 3 = 'Sometimes', 2 = 'Rarely', and 1 = 'Never'. Questions 176-250 are to evaluate teacher professional behaviour in classroom situations. The 3-point Likert scale is used for the set of questions between 176 - 197 with 3 meaning 'Definitely', $2=$ 'Maybe', and $1=$ 'Definitely not'. The rest of the questions are of a multiple-choice type. The test was validated by developers and was considered mutually validated.

Appendix B: The checklist on students' performance in PISA-purposed materials design and teaching methodology

The checklist consists of 10 questions and it is based on 4- point Likert scale with $1=$ not at all; $2=$ slightly; $3=$ somewhat; 4 = completely. The validation procedure showed 'good validity' of the checklist. The values for the item-level content validity index (IL-CVI) of the checklist were between 0.82 and 0.88 . The Kappa coefficient values were between 0.85 and 0.89 .

\section{E. The focus group interview questionnaire}

The questionnaire consisted of 4 open-ended questions and was administered to 9 randomly selected sampled students. The interviews were conducted via the Cisco Webex video conferencing tool. These were recorded and transcribed. When analysing, the respondents' opinions were grouped by themes and assigned codes by research team members.

Question 1. What is your impression of the reshaped curriculum for undergraduates majoring in primary school teaching and learning based on PISA-based test specifics and aimed at fostering the key competencies needed for training schoolchildren to succeed in the test? Why?

Question 2. How did you personally benefit from the updated programme of training and internship experience? Explain your reasoning.

Question 3. What discouraged you from getting engaged in training and internship activities? Why?

Question 4. Would you recommend the programme to your peers? Why?

\section{RESULTS}

The study output is presented in three basic sections each addressing a specific research question. These were as follows: the results of administering the baseline phase PISA awareness quiz, intervention results based on pretest and posttest measurements, and focus group interview to identify the perception of the upgraded specialism-related training by EG students.

A. The results of the baseline phase: PISA awareness quiz

The population of 712 current students majoring in primary school teaching and learning, academic instructors, and school teachers participated in this empirical measurement.

Table. 2. Results of the empirical measurement of the students', academic instructors' and school teachers' awareness of PISA-based

\begin{tabular}{|c|c|c|c|c|c|}
\hline Domain & $\begin{array}{c}\text { Reference } \\
\text { values }\end{array}$ & Mean & $S D$ & $\begin{array}{c}p-\text { value } \\
\text { normal } \\
\text { distribution }\end{array}$ & $d f$ \\
\hline Question Types & 4 & 2.39 & 1.092 & 0.10057 & 710 \\
\hline $\begin{array}{l}\text { Question } \\
\text { Wording }\end{array}$ & 4 & 2.51 & 1.046 & 0.074031 & 710 \\
\hline $\begin{array}{l}\text { Response } \\
\text { Options }\end{array}$ & 3 & 2.09 & 0.774 & 0.079493 & 709 \\
\hline Scaled Indices & 2 & 1.56 & 0.496 & 0.12944 & 711 \\
\hline Routing & 1 & 0.40 & 0.491 & 0.88697 & 709 \\
\hline $\begin{array}{l}\text { Matrix } \\
\text { Sampling }\end{array}$ & 2 & 0.85 & 0.755 & 0.57161 & 711 \\
\hline Test format & 4 & 1.63 & 1.250 & 0.28944 & 710 \\
\hline
\end{tabular}

As can be seen in Table 2, the mean values for the students', academic instructors' and school teachers' awareness of a PISA-based test were almost twice as low as the reference 
values. These suggested that the training to raise the students' awareness of the PISA-based test was necessary.

\section{B. Intervention results}

The purpose of the intervention was to identify how the reshaped curriculum for undergraduates majoring in primary school teaching and learning influenced the key competencies that are needed to teach schoolchildren so that they are ready for the PISA-based test and how the host educational institutions evaluated the sampled students' professional efficacy while they did internships in terms of PISA-purposed materials design and teaching methodology. The calculations were performed using the Paired T-Test (two-tailed). Table 3 presents the descriptive statistics drawn from the pre-and postintervention measurements.

Table. 3. Descriptive statistics drawn from the pre-and postintervention measurements $(\mathrm{n}=44$

\begin{tabular}{|c|c|c|c|c|c|c|c|c|}
\hline \multirow[t]{2}{*}{ Variable } & \multicolumn{2}{|c|}{ B } & \multicolumn{2}{|c|}{ A } & \multirow[t]{2}{*}{$p$ normality } & \multirow[t]{2}{*}{$t$} & \multirow[t]{2}{*}{$d$} & \multirow[t]{2}{*}{$d f$} \\
\hline & $M$ & $S D$ & $M$ & $S D$ & & & & \\
\hline GPA & $\begin{array}{l}73 . \\
57\end{array}$ & $\begin{array}{l}2 . \\
24\end{array}$ & $\begin{array}{l}84 . \\
64\end{array}$ & $\begin{array}{c}3 . \\
29\end{array}$ & 0.4924 & 11.5604 & 3.09 & 43 \\
\hline TAT & $\begin{array}{l}43 . \\
85\end{array}$ & $\begin{array}{l}5 . \\
74\end{array}$ & $\begin{array}{c}70 . \\
35\end{array}$ & $\begin{array}{l}11 . \\
00\end{array}$ & 0.198 & 8.2332 & 2.2 & 43 \\
\hline IGA & $\begin{array}{l}69 . \\
42\end{array}$ & $\begin{array}{l}4 . \\
65\end{array}$ & $\begin{array}{c}80 . \\
00\end{array}$ & $\begin{array}{l}4 . \\
91\end{array}$ & 0.9077 & 5.8154 & 1.55 & 42 \\
\hline
\end{tabular}

Note: GPA - grade point average (ECTS); TAT - Teacher Aptitude

Test; IGA - Internship Grade Averaged (ECTS), B- Before the intervention (at the beginning of internship); A- After the intervention (at the end of internship).

As can be noticed in Table 3, there were positive, substantial, and significant changes in all variables under study. The calculations showed a large observed effect size which was 3.09 for GPA, 2.2 for TAT, and 1.55 for IGA. The difference between pre-and after-intervention Mean values for GPA was -11.07. The standard deviation of the difference, S' equaled 0.958 . The test statistic $\mathrm{T}$ equaled 11.5604 , which was not in the 95\%region of acceptance: [-2.1604 : 2.1604]. $\mathrm{x}=11.07$, was not in the 95\%region of acceptance: [-2.069 : 2.069].

The difference between pre-and after-intervention Mean values for TAT was -26.77 . The standard deviation of the difference, $S^{\prime}$ equaled 3.219. The test statistic T equals 8.2332, which was not in the 95\%region of acceptance: [-2.1604 : 2.1604]. $x=26.5$, was not in the 95\% region of acceptance: [$6.9535: 6.9535]$.

The difference between pre-and after-intervention Mean values for IGA was -10.58. The standard deviation of the difference, $\mathrm{S}^{\prime}$ equaled 1.818. The test statistic $\mathrm{T}$ equaled5.8154, which was not in the 95\% region of acceptance: [-2.1604: 2.1604]. $\mathrm{x}=10.57$, was not in the 95\%region of acceptance: [-3.9272: 3.9272].

\section{Focus group interview}

Question 1. Nine students reported that the project was a positively challenging experience. It helped them to 'pump up' their intellectual, professional, and technical skills. They reported improvement in awareness of the PISA-based test, Blooms' Taxonomy, and test questions formulation. The interviewees informed that they learned to use DIF and DTF methods to validate the PISA test questions, age specifics in training primary school children in terms of adjusting it taking the PISA-based test, and approaches to creating a positive mindset in primary schoolchildren towards learning through dialogue and cooperation. Some of the students' quotes were as follows:

[... the PISA-based trainings made me feel lagging behind in teaching methods...]

[... Blooms' Taxonomy and DIF and DTF methods often made me crazy...]

[... I'm really grateful to my tutors and supervisors from the host schools for my teaching experiences...]

Question 2. Five students reported that they upgraded their teaching and material design skills. Four students responded that they became more confident as teachers in terms of PISAbased test training. Their reasoning was as follows:

[...because the trainings raised standards of teaching and it created the learning environment based on competition with equal opportunities for everyone...]

Question 3. All respondents confessed that they were mostly discouraged and disappointed by the criticisms and feedbacks from their tutors, observers, and host school teachers. Additionally, the deadlines for designing materials were quite harsh.

[... some critics and feedback were tactless and hurtful...]

[... sometimes I felt like changing the host school to continue my internship...]

Question 4. Six students suggested introducing some training in providing feedback. Three students recommended using the face-to-face approach to providing feedback. They are sure that the above will reduce or eliminate tensions in relations between the students and the tutors/supervisors.

\section{Limitations of the study}

The sampling method used in the intervention phase of the study may be considered to be a limitation of this study.

\section{DISCUSSION}

The study is novel for the school educational settings in Ukraine because the shift to training schoolchildren to take PISA-based test is an emerging instructional trend that requires reshaping the preservice teacher professional training, specifically in test format, materials design, and assessment. Given this, the intervention part of the study attempted to address the loopholes in the university curriculums and training of the students majoring in primary education. This target audience was chosen because it is important to start upgrading the school instructional model from very point A so that the students were ready at point B. Changing the students' perceptions and their teaching approaches were the major difficulties and challenges to the study. They were addressed through mentorship which was used when the students did internships.

Overall, the study attempted to answer several questions such as to what extend the student teachers were aware of the PISA-based test; how the reshaped curriculum for 
undergraduates majoring in primary school teaching and learning fostered the key competencies that are needed to teach schoolchildren so that they are ready for the PISA-based test; how the host educational institutions evaluated the sampled students' professional efficacy while they did internships in terms of PISA-purposed materials design and teaching methodology, and how the EG students perceived the upgraded specialism-related training.

The PISA awareness quiz that was administered to the population of 712 current students majoring in primary school teaching and learning, academic instructors, and school teachers showed that the mean values for the students', academic instructors' and school teachers' awareness of PISAbased test were almost twice as low as the reference values. These suggested that the training to raise the students' awareness of the PISA-based test was necessary.

The reshaped curriculum and instructional model led to positive, substantial, and significant changes in all variables under study. The calculations showed a large observed effect size which was 3.09 for GPA, 2.2 for TAT, and 1.55 for IGA. The difference between pre-and after-intervention Mean values for GPA was -11.07. The standard deviation of the difference, $\mathrm{S}^{\prime}$ equaled 0.958 . The test statistic $\mathrm{T}$ equaled 11.5604, which was not in the 95\%region of acceptance: [-2.1604: 2.1604]. $\mathrm{x}=11.07$, was not in the 95\% region of acceptance: [-2.069: 2.069]. The difference between pre-and after-intervention Mean values for TAT was -26.77. The standard deviation of the difference, $\mathrm{S}^{\prime}$ equaled 3.219. The test statistic $\mathrm{T}$ equals 8.2332, which was not in the $95 \%$ region of acceptance: [2.1604: 2.1604]. $x=26.5$, was not in the $95 \%$ region of acceptance: [-6.9535: 6.9535]. The difference between pre-and after-intervention Mean values for IGA was -10.58. The standard deviation of the difference, $\mathrm{S}^{\prime}$ equaled 1.818 . The test statistic $\mathrm{T}$ equaled5.8154, which was not in the 95\%region of acceptance: [-2.1604: 2.1604]. $\mathrm{x}=10.57$, was not in the 95\%region of acceptance: [-3.9272: 3.9272].

The above positive changes were illustrated and supported by the results yielded from the focus group interview that was administered to 9 randomly selected students. The interviewees reported that the project was a positively challenging experience. It helped them to 'pump up' their intellectual, professional, and technical skills. They reported improvement in awareness of the PISA-based test, Blooms' Taxonomy, and test questions formulation. The students informed that they learned to use DIF and DTF methods to validate the PISA test questions, age specifics in training primary school children in terms of adjusting it taking the PISA-based test, and approaches to creating a positive mindset in primary schoolchildren towards learning through dialogue and cooperation. The students reported that they upgraded their teaching and material design skills and became more confident as teachers in terms of PISA-based test training.

The findings presented above align with the previous research. The study is consistent with authors [18] who found that the respondents showed a lack of confidence in their understanding of PISA. It also goes in line with researchers [19], [20] who revealed that those students who receive training were aware of PISA-based tests. They were found that more than half of the students believed that PISA highly impacted their job functions, just almost half of them were sure that PISA results are reliable. The above results implied that pre-service teachers' judgments lacked awareness.

The results drawn for the intervention are consistent with Berliner implying that pre-service training needs reshaping that curriculum and instruction to adhere to certain principles of PISA design [21]. The study agrees with researcher [22] who recommends introducing the modules in the training programme of the pre-service teachers to familiarise them with PISA and train the test-related skills in them so that they could train the schoolchildren when they have graduated [22].

The finding related to the upgrading the school instructional model from very point A so that the students were ready at point B agrees with Olsen and Nilsen [2] who concluded that PISA procedure - along with training teachers in training students to take it and to administer it - could not cover every issue of the complexity of grading students in school. However, training instructors the data collected could develop guidelines on how to improve teaching methods and models.

The findings from the study are in character with researchers [23], [24], [25] and support their claims regarding a disconnect between the preservice teacher training program and objectives of educational organisations.

\section{CONCLUSION}

It is necessary for the school educational settings in Ukraine that there was reshaped the preservice teacher professional training, specifically in test format, materials design, and assessment, and made the shift to training schoolchildren to take PISA-based test which is an emerging international instructional trend. The teacher students' awareness of the PISA-based test needs improvement. The training model used in the study along with internship addresses the loopholes in the university curriculums and training of the students majoring in primary education. The intervention brought a positively challenging experience for the students. It helped them to 'pump up' their intellectual, professional, and technical skills. They raised awareness of the PISA-based test, Blooms' Taxonomy, and test question formulation. The students learned to use DIF and DTF methods to validate the PISA test questions, age specifics in training primary school children in terms of adjusting it taking the PISA-based test, and approaches to creating a positive mindset in primary schoolchildren towards learning through dialogue and cooperation. It was found that the students upgraded their teaching and material design skills and became more confident as teachers in terms of PISA-based test training. It was also revealed that changing the students' perceptions and their teaching approaches were the major difficulties and challenges to the study. They were addressed through mentorship which was used when the students did internships. 
Further research is needed on contextual factors that might influence pre-service students' engagement in PISA training.

\section{ACKNOWLEDGMENT}

We are grateful to host schools for providing venues for internships. We are thankful to the supervisors for their contribution to the quality of students' instruction and material design. We are also appreciative to all the sampled students and trainers for making the intervention and internship smooth to complete.

\section{REFERENCES}

[1] OECD. "PISA 2018 Questionnaire Framework. In PISA 2018 Assessment and Analytical Framework. OECD Publishing." $2019 . \quad$ Available: https://doi.org/10.1787/850d0ef8-en

[2] R. V. Olsen, and T. Nilsen, "Standard setting in PISA and TIMSS and how these procedures can be used nationally," In Standard Setting in Education. Methodology of Educational Measurement and Assessment. New York: Springer, 2017. https://doi.org/10.1007/978-3-319-508566_5

[3] A. Schleicher, "PISA 2018: Insights and Interpretations," OECD Publishing, 2019 Available: https://www.oecd.org/pisa/PISA\%202018\%20Insights\%2 0and\%20Interpretations\%20FINAL\%20PDF.pdf

[4] PISA, "Between performance and well-being," Education International, 2020. Available: https://www.eiie.org/en/detail/16567/pisa-2018-between-performanceand-well-being

[5] M. Mazorchuk, T. Vakulenko, V. Tereshchenko, G. Bychko, K. Shumova, S. Rakov, and V. Gorokh, "National report based on the results drawn from PISA2018 international study on the quality of education. Ukrainian Center for Educational Quality Assessment," 2019. Available: https://testportal.gov.ua/wpcontent/uploads/2019/12/PISA _2018_Report_UKR.pdf

[6] OECD, "International Benchmarking for School Improvement," $2013 . \quad$ Available: http://www.oecd.org/pisa/aboutpisa/OECD\%20Test\%20fo r\%20Schools\%20Brochure.pdf

[7] D. Caro, and L. Kyriakides, "Assessment design and quality of inferences in PISA: limitations and recommendations for improvement. Assessment in Education: Principles," Policy Pract, vol. 26, no. 4, pp. 363-368,

2019. https://doi.org/10.1080/0969594X.2019.1645990

[8] W. Wasis, S. Sukarmin, and M. Prastiwi, "Cognitive process analysis of PISA, TIMSS, and UN science items based on revised Bloom Taxonomy," J Comput Theor Nanosci, vol. 23, no.12, pp. 12068-12072, 2017. https://doi.org/10.1166/asl.2017.10575

[9] A. Nikolić-Vučinić, I. Mrvaljević, O. Nikolić, V. Tomić, V. Bulatović, N. Durković, and D. Šćekić, "PISA 2015 results and education policy recommendations. UNICEF Country Office in Montenegro," 2019. Available:
https://www.unicef.org/montenegro/media/8686/file/MNE -media-MNEpublication501.pdf

[10]F. E. Tonga, S. Eryiğit, F. A. Yalçın, and F. T. Erden, "Professional development of teachers in PISA achiever countries: Finland, Estonia, Japan, Singapore, and China. Professional Development in Education," 2019. Available: https://open.metu.edu.tr/handle/11511/30889

[11]D. Pettersson, and C. E. Molstad, "PISA teachers: The hope and the happening of educational development," Educ Soc, vol. 37, no. 136, pp. 629-645, 2016. https://doi.org/10.1590/es0101-73302016165509

[12] J. Schoonenboom, and R. B. Johnson, "How to Construct a Mixed Methods Research Design," J Social Soc Psychol, vol. 69, no. 2, pp. 107-131, 2017. https://doi.org/10.1007/s11577-017-0454-1

[13] S. McCombes, "Descriptive research. Scribbr," 2019. Available:

https://www.scribbr.com/methodology/descriptiveresearch/

[14] S. McCombes, "How to create a research design. Scribbr," 2020 Available: https://www.scribbr.com/research-process/researchdesign/

[15]J. McKinley, and H. Rose, (Eds.), "Experimental and quasi-experimental designs" In The Routledge Handbook of Research Methods in Applied Linguistics. Oxford: Routledge, 2020. https://doi.org/10.4324/9780367824471

[16]J. Bertling, and J. Alegre, "The PISA 2021 context questionnaires - Balancing continuity with efficiency and innovation. OECD," 2019. Available: https://www.oecd.org/pisa/sitedocument/PISA-2021questionnaire-framework.pdf

[17]K. S. Taber, “The use of Cronbach's Alpha when developing and reporting research instruments in science education," Res Scie Educ, vol. 48, pp. 1273-1296, 2018. https://doi.org/10.1007/s11165-016-9602-2

[18] D. S. M. Mohamed, S. H. Sahminan, G. A. Len, and M. Shahrill, 'Teachers' awareness, understanding, and challenges regarding the PISA implementation. In: AIP Conference Proceedings, 2194, the 2nd International Conference on Science, Mathematics, Environment, and Education., 2019.

[19] O. Ioannidou, D. Georgiou, A. Obersteiner, N. D. Baş, and C. Mieslinger, "Do Prospective Teachers Care About PISA Studies?" A Pilot Study among University Students in Germany. Int Educ Stud, vol. 10, no. 5, pp. 26-34, 2017. https://doi.org/10.5539/ies.v10n5p26

[20] Tshering, and Choeda. "Pre-service teacher's perspectives on the Programme for International Student Assessment for Development (PISA-D): A case of Samtse College of Education," Int J Eng Liter Soc Scie, vol. 5, no. 1, pp. 6166, 2020. https://dx.doi.org/10.22161/ijels.51.12

[21]D. C. Berliner, "The implications of understanding that PISA is simply another standardized achievement test," In Handbook of Education Policy Studies. New York: Springer, 2020.

[22] S. Sjøberg, "PISA and global educational governance: A critique of the project, its use, and implications," Eur $J$ 
Math, Scie Technol Educ, vol. 11, no. 1, pp. 111-127, 2015. https://doi.org/10.12973/eurasia.2015.1310a

[23] S. Chennat, "Internship in a pre-service teacher education programme: A global perspective," IMPACT: Int J Res in Appl, Natural Soc Scie, vol. 2, no.11, pp. 79-93, 2014.

[24]S. Greve, K. E. Weber, B. Brandes, and J. Maier, "Development of pre-service teachers' teaching performance in physical education during a long-term internship," Germ J Exerc Sport Res, vol. 50, pp. 343353, 2020. https://doi.org/10.1007/s12662-020-00651-0

[25]T. L. H Nghia, and H. N. Tai, "Preservice teachers' experiences with internship-related challenges in regional schools and their career intention: implications for teacher education programs," J Early Child Teach Educ, vol. 40, no. $2, \quad$ pp. 2019. https://doi.org/10.1080/10901027.2018.1536902

\section{Creative Commons Attribution License 4.0 (Attribution 4.0 International, CC BY 4.0)}

This article is published under the terms of the Creative Commons Attribution License 4.0

https://creativecommons.org/licenses/by/4.0/deed.en_US 